\title{
Penggunaan Model Pembelajaran Student Centered Learning (SCL) Pada Mata Kuliah Kimia Bahan Alam
}

\author{
Lili Andriyani
}

STIKES Harapan Ibu Jambi

$\risingdotseq$ e-mail: liliandriyani116@gmai.com

\begin{abstract}
The learning process that implements the lecturers as the only source of knowledge, it turns out that in fact gives rise to a variety of polemics in the education field, including not motivation students to study more enterprising and find other resources relevant to the field of science. Natural Products Chemistry course is the course that are associated with the natural surroundings, so it takes a model of learning which increase the curiosity of the students will be the condition of the environment. The application of the model of Student Centered Learning (SCL) is one model that could be applied in learning so that an increase in the motivation to learn.
\end{abstract}

Keyword: student centered learning, natural products chemistry

Copyright (C) 2018 IICET (Indonesia) - All Rights Reserved

Indonesian Institute for Counseling, Education and Therapy (IICET)

\section{PENDAHULUAN}

Pendidikan merupakan salah satu faktor pendukung majunya suatu bangsa. Jika pendidikan di suatu daerah baik, maka bisa dipastikan daerah tersebut juga akan maju. Hal ini karena sejalan antara kemampuan berpikir masyarakat dengan paradigma pembangunan yang ada.

Salah satu indikator keberhasilan proses pendidikan dapat dilihat dari motivasi peserta didik. Hal ini bisa akan terlihat dalam proses pembelajaran. Jika peserta didik sudah termotivasi untuk belajar, maka hasil belajarnya pun akan meningkat. Peningkatan hasil belajar mahasiswa merupakan tantangan suatu Perguruan Tinggi, namun berbagai kendala dihadapi dalam mencapai tujuan tersebut, baik dari segi pendidik, peserta didik, maupun sumber belajar.

Kendala muncul ketika sesuatu yang diharapkan tercapai dari proses itu tidak menjadi kenyataan. Suasana kelas sangat mempengaruhi semangat mahasiswa dan dosen untuk saling bekerja sama dalam mencapai tujuan pembelajaran. Kebanyakan dosen lebih memilih metode ceramah sebagai metode pembelajaran. Hal ini karena diyakini akan membantu mahasiswa dalam memahami materi yang diberikan, namun ternyata metode tersebut kurang cocok untuk dilaksanakan terlebih untuk mata kuliah Kimia Bahan Alam. Materi Kimia Bahan Alam membutuhkan pemahaman lebih dari mahasiswa karena banyak hal abstrak yang dipelajari. Metode ceramah yang diberikan terkadang malah membuat mahasiswa menjadi kurang fokus karena bosan dengan materi tersebut terlebih banyak yang kurang paham dengan konsep dasarnya. Sistem pembelajaran Teacher Centered Learning (TCL) yang diterapkan di kelas ternyata membuat kreativitas mahasiswa kurang terpupuk, kurang kreatif, dan tidak dapat segera menyesuaikan diri dengan kemajuan zaman (Hadi 2007, Harsono 2008, Kurdi 2009), sementara itu mahasiswa duduk mendengarkan ceramah dengan aktivitas minimal(Harsono 2006). 
Akibatnya ketika kondisi tersebut masih berlangsung dalam proses belajar mengajar, maka kualitas pembelajaran menjadi menurun. Hal ini terlihat dari sedikitnya mahasiswa yang memberikan tanggapan pada saat perkuliahan dan nilai IPK rata-rata mahasiswa pada waktu semester 3 masih rendah. Oleh sebab itu pada kuliah Kimia Bahan Alam perlu adanya alternatif pembelajaran yang berorientasi pada keaktifan mahasiswa. Dimana mahasiswa berusaha menggali informasi sebanyak-banyaknya terkait materi yang diberikan, menghubungkan materi dengan aplikasinya dalam kehidupan, serta mampu berinteraksi dengan dosen dan sesama mahasiswa. Salah satunya dengan penerapan Student Center Learning (SCL) dalam pembelajaran dan dosen berperan sebagai fasilitator dalam mengawasi dan memonitor jalannya diskusi kelas (Tärnvik 2007), sehingga akan dihasilkan mahasiswa yang berjiwa bebas dan mampu berpikir kreatif (Brown 2008). Berbagai penelitian sudah membuktikan bahwa penggunaan SCL dapat meningkatkan hasil belajar (Murshidi 2014, Wright 2011).

\section{METODOLOGI}

Metode penelitian dilakukan dengan melakukan wawancara secara langsung kepada 16 orang mahasiswa semester 4 perwakilan dari masing-masing kelas. Penelitian diadakan di Prodi Farmasi, Stikes Harapan Ibu Jambi, dari bulan April-Juli 2017.

\section{HASIL DAN PEMBAHASAN}

\section{Hasil}

Penerapan SCL dilakukan pada mata kuliah Kimia Bahan Alam selama 8x pertemuan dengan mahasiswa semester 4 Stikes Harapan Ibu Jambi. Wawancara dengan perwakilan mahasiswa dari masingmasing kelas seperti berikut :

-Perwakilan mahasiswa 4A.

Secara garis besar setiap perwakilan menyatakan bahwa SCL yang diterapkan pada mata kuliah Kimia Bahan Alam lebih disukai, mahasiswa belajar aktif, bertanggung jawab atas tugas yang sudah diberikan, lebih termotivasi dalam kuliah, materi mudah dipahami, dan menarik. Dari segi kelemahannya yaitu bagi mahasiswa yang kurang aktif dalam pembelajaran maka akan mendapat nilai rendah.

-Perwakilan 4B

Penerapan SCL dinilai efektif bagi mahasiswa, selain itu mahasiswa dituntut untuk lebih rajin dalam mencari sumber yang lain, lebih nyaman dalam mengungkapkan pertanyaan, lebih berani berbicara, dan lebih mudah memahami materi. Kelemahannya SCL antara lain kurang menyeimbangkan antara mahasiswa yang aktif dan yang pasif. Mahasiswa aktif akan semakin maju, dan yang pasif malah semakin mundur.

-Perwakilan 4C

Adanya pembelajaran dengan SCL mampu memancing semangat untuk berpikir, sumber yang dibaca semakin banyak, dan suasana di kelas menjadi lebih santai. Namun dengan SCL materi yang disampaikan oleh mahasiswa terkadang kurang lengkap, ketika ada sesuatu yang mengganjal masih ada beberapa mahasiswa yang enggan untuk mengemukakan pendapat.

\section{Pembahasan}

Penerapan model pembelajaran SCL efektif digunakan untuk mata kuliah Kimia Bahan Alam. Hal ini terlihat dari hasil wawancara terhadap perwakilan mahasiswa masing-masing kelas. Secara umum mahasiswa menyatakan kesetujuannya dengan penggunaan SCL dalam proses belajar-mengajar.

Terjadinya kesinambungan antara minat mahasiswa dengan tuntutan yang diberikan oleh SCL turut mendorong keberhasilan model pembelajaran ini. Pada model SCL mahasiswa harus memiliki motivasi yang tinggi guna mencapai target yang sudah diberikan. Hal yang sudah dilakukan pada proses pembelajaran adalah dengan memberikan tugas sebelum perkuliahan dimulai. Setelah itu masing-masing kelompok yang beranggotakan dua orang tampil di depan kelas guna mempresentasikan dan mendiskusikan hasil yang diperoleh. Tindakan seperti ini memaksa mahasiswa untuk berani mengemukakan pendapat dan memberikan tanggapan terhadap materi yang disajikan serta tidak takut dengan dosen. 
Hasil wawancara membuktikan bahwa mahasiswa sudah mulai berani untuk berpendapat, meskipun masih ada beberapa yang kurang aktif. Ke depannya diharapkan semua mahasiswa akan aktif dalam perkuliahan. Keaktifan mahasiswa muncul jika sudah timbul motivasi dalam diri mahasiswa. Motivasi mampu menimbulkan kemauan dalam melaksanakan suatu kegiatan (Suprihatin 2015)

Pada Student Centered Learning mahasiswa berperan aktif dari awal, berpikir kritis tentang materi pelajaran, merangsang diskusi dan debat, mendorong timbulnya pertanyaan-pertanyaan bahkan membuat mahasiswa saling mengajar satu sama lain (Muqarramah 2016).

\section{SIMPULAN DAN SARAN}

Model pembelajaran SCL bisa diterapkan dalam pembelajaran Kimia Bahan Alam karena menuntut mahasiswa untuk lebih aktif mencari sumber lain yang relevan dan bisa menjelaskan materi yang telah dipelajari melalui presentasi dan diskusi kelas. Terlihat motivasi mahasiswa semakin meningkat dan timbul keberanian untuk berani mengemukakan pendapat di dalam kelas.

\section{DAFTAR RUJUKAN}

Brown, J.K., (2008). Student-Centered Instruction: Involving Students in Their Own Education. Music Educators Journal, 94(5), pp.30-35.

Hadi, R. (2007). Dari Teacher- Teacher - Centered Learning ke Student- Student - Centereded Learning. Jurnal Pemikiran Alternatif Pendidikan, 12(3), pp.1-8.

Harsono. (2006). Kearifan dalam Transformasi Pembelajaran : Jurnal Pendidikan Kedokteran den Profesi Kesehatan Indonesia, I(1), pp.1-6.

Harsono. (2008). Student-Centered Learning di Perguruan Tinggi. Jurnal Pendidikan Kedokteran dan Profesi Kesehatan Indonesia, 3(1), pp.4-8.

Kurdi, F.N. (2009). Penerapan Student-Centered Learning Dari Teacher-Centered Learning Mata Ajar Ilmu Kesehatan Pada Program Studi Penjaskes. Forum Kependidikan, 28(2), pp.108-113.

Muqarramah. (2016). Pendekatan Student Centered Learning; Design Pembelajaran Aqidah Akhlak. Jurnal Tarbiyah (Jurnal Ilmiah Kependidikan), 5(2), pp.23-43.

Murshidi, G. Al. (2014). The Impact Of Student-Centered Learning Approach Through Workshops Conduction On The Uae University Female Students' Confidence. European Journal of Business and Management Review, 2(5), pp.31-43.

Suprihatin, S. (2015). Upaya Guru Dalam Meningkatkan Motivasi Belajar Siswa. Jurnal Promosi, 3(1), pp.73-82.

Tärnvik, A. (2007). Revival of the case method: a way to retain student-centred learning in a post-PBL era. Journal Medical Teacher, 29(1), pp.32-36.

Wright, G.B. (2011). Student-Centered Learning in Higher Education. International Journal of Teaching and Learning in Higher Education, 23(3), pp.92-97. 